\title{
Use of Antibiotics for Selective Isolation and Enumeration of Actinomycetes in Soil
}

\author{
By S. T. WILLIAMS and F. L. DAVIES \\ Hartley Botanical Laboratories, University of Liverpool
}

(Received 17 August 1964)

\begin{abstract}
SUMMARY
Several antibiotics were tested against a range of actinomycetes, bacteria and fungi representing types found in soil. From these tests four antibiotics, nystatin (50 $\mu \mathrm{g} . / \mathrm{ml}$.$) , actidione (50 \mu \mathrm{g} . / \mathrm{ml}$.$) , polymyxin B sul-$ phate $(5 \cdot 0 \mu \mathrm{g} . / \mathrm{ml}$.) and sodium penicillin $(1 \cdot 0 \mu \mathrm{g} . / \mathrm{ml}$.), were selected for incorporation into a starch + casein medium to achieve selective growth of actinomycetes on soil dilution plates. This mixture of antibiotics was tested with a number of soils and its efficiency compared with several other methods for selective development of actinomycete colonies. The most suitable mixture for the enumeration of soil actinomycete colonies was starch + casein medium with the two antifungal antibiotics (nystatin, actidione); for isolation of actinomycete colonies the same medium with all four antibiotics was the most satisfactory.
\end{abstract}

\section{INTRODUCTION}

Studies of actinomycetes in soil are usually made with the dilution plate technique. The number of propagules of these organisms in most soils is intermediate between those of bacteria and fungi, so dilutions suitable for colony counting or isolation allow the development of large numbers of bacteria. At such dilutions the numbers of fungal colonies are usually low, but with their large radial spread they can still interfere with the analysis of actinomycetes on the plates. In acid soils, relative numbers of fungal colonies are often high enough to make analysis impossible. Many attempts have been made to overcome these problems, including the use of selective nutrients in media, pre-treatment of soil samples or soil suspensions, and incorporation of selective inhibitors into media.

Several substances have been suggested as selective substrates for actinomycetes. The use of L-arginine as a selective nitrogen source favouring actinomycetes over bacteria was reported by Porter, Wilhelm \& Tresner (1960) and El Nakeeb \& Lechevalier (1963). Küster \& Williams (1964), who examined several carbon and nitrogen sources, found starch (or glycerol) + casein + nitrate to be the most selective mixture. Use of chitin as sole carbon and nitrogen source was recommended by Lingappa \& Lockwood $(1961,1962)$.

Tsao, Leben \& Keitt (1960) reported increased selective development of actinomycetes when air-dried soil was re-moistened, mixed with calcium carbonate and incubated at $28^{\circ}$. Agate \& Bhat (1963) attempted suppression of bacteria and fungi by pre-incubation of soil at $110^{\circ}$ for $10 \mathrm{~min}$. and the use of dried plates. Methods such as these are of little use for ecological studies, where the situation in the soil 
at the time of sampling is of prime interest. Treatment of soil suspensions with a $1.4 \%(w / v)$ phenol solution was recommended by Lawrence (1956); Reháček (1959) centrifuged suspensions at speeds selected to separate actinomycete spores from other propagules. In a comparative study of som€ of these methods, El Nakeeb \& Lechevalier (1963) found that the calcium carbonate treatment gave highest colony counts, while the centrifugation and phenol treatments gave counts lower than those from untreated suspensions.

Many workers have used antibiotics in media to achieve selective inhibition of various groups of organisms. The use of antibacterial antibiotics to improve the efficiency of media for isolating fungi has been reported by Martin (1950), Johnson (1957), and others. Antibiotics which inhibit fungi have been found particularly useful in studies on actinomycetes. Actidione (cycloheximide) has been used by Dulaney, Larsen \& Stapley (1955), Corke \& Chase (1956, 1964), Corbaz, Gregory \& Lacey (1963) and Porter et al. (1960) who also recommended nystatin and pimaricin. To achieve suppression of bacteria while allowing growth of actinomycetes presents more difficulties since most antibacterial antibiotics also inhibit actinomycetes. Porter et al. (1960) reported that attempts to obtain selective inhibition of bacteria with antibiotics were unsuccessful, but Dulaney et al. (1955) recommended a mixture of antibacterial and antifungal antibiotics to allow selective development of actinomycetes.

Although many workers have used antibiotics in media to select actinomycetes, few details are available about their relative effects on the various groups of soil organisms, either in pure culture or on soil dilution plates. Therefore it was decided to make a study of the value of the use of antifungal and antibacterial antibiotics for the selective isolation and enumeration of actinomycetes. The antibiotics were tested in the starch casein medium already shown to be selective for actinomycetes by Küster \& Williams (1964). The effect of antibiotics, singly and in admixture, on pure cultures of soil-inhabiting organisms was first studied. The antibiotics selected from these tests were then used to prepare soil dilution plates in several comparative experiments.

\section{METHODS}

Selection of antibiotics. The antibiotics to be used in detailed tests were selected by a preliminary experiment in which they were tested against a range of actinomycetes. The antibiotics used were Nystatin (Squibb); Actidione (Light); Polymyxin B sulphate (Burroughs Wellcome); sodium benzyl penicillin (Glaxo);:Streptomycin sulphate (Glaxo); Chloramphenicol (Allen and Hanburys); Chlortetracycline hydrochloride (Cyanamid).

The test organisms were 45 Streptomyces species, Micromonospora melanosporea, Waksmania rosea and a Streptosporangium sp. These tests and subsequent ones in this work were done with a starch + casein medium adjusted to $\mathrm{pH} 7 \cdot 0$ (Küster \& Williams, 1964). Solutions of the sterile antibiotics were prepared in sterile water; for the insoluble nystatin a suspension was made. Antibiotic solutions were added to molten medium at $45^{\circ}$ to give concentrations of $0,1 \cdot 0,5 \cdot 0,10 \cdot 0,30 \cdot 0,50 \cdot 0$, and $100 \cdot 0 \mu \mathrm{g} . / \mathrm{ml}$. One-ml. samples of spore suspensions of test organisms were mixed with $9 \mathrm{ml}$. samples of media and plates poured. Spore suspensions were prepared by incorporating one loopful of a mature sporing culture into $10 \mathrm{ml}$. of sterile water. 
Plates were incubated at $\mathbf{2 5}^{\circ}$ for 7 days; development of micro-organisms on antibiotic plates were compared with that on control plates and any inhibition of growth noted.

Testing of selected antibiotics against actinomycetes, bacteria and fungi. The four antibiotics selected from the preliminary tests were then tested against cultures of soil-inhabiting organisms comprising 25 bacteria, 30 fungi and 114 actinomycetes. The four antibiotics were tested in various mixtures, the method of testing being as described, except that several tenfold dilutions of the suspensions of test organisms were plated. The dilutions selected for reading were those giving about 100 colonies/ plate for bacteria, 50 for actinomycetes and 10 for fungi. By this means, masking of inhibition by over-concentrated suspensions was avoided. Results were recorded after incubation for 14 days at $25^{\circ}$, by comparison of antibiotic plates with control plates. Inhibition was recorded as 'complete' = no growth, 'partial' diminished growth and 'none' = growth identical with controls.

Comparison of soil dilution plates prepared with and without antibiotics. Experiments were done to study the effect of the antibiotics selected from the tests on pure cultures, on the dilution plate colony counts of organisms from several soil samples. The soils used were a garden soil from Ness, Cheshire ( $\mathrm{pH} 5 \cdot 4$ ), a garden soil from Oxton, Cheshire (pH 6.2) and two horizons from a forest soil at Freshfield, Lancashire, the $\mathrm{A}$ horizon being at $\mathrm{pH} 4 \cdot 2-5 \cdot 8$ and the $\mathrm{C}$ horizon at $\mathrm{pH} 7 \cdot 2-8 \cdot 6$. These soils differed considerably in their total microbial content and in the relative proportions of actinomycetes, bacteria and fungi. Thus they were suitable for making an assessment of the various antibiotics for obtaining selective growth of actinomycetes.

Preparation of dilution plates. Soil (1 g.) was added to $100 \mathrm{ml}$. sterile water in a screw-top bottle and shaken on a reciprocal shaker for $30 \mathrm{~min}$. From the resulting suspension tenfold dilutions were prepared; $10 \mathrm{ml}$. samples of these were used to seed $90 \mathrm{ml}$. molten starch + casein medium at $45^{\circ}$, the antibiotics when used being added to the medium at the selected concentrations just before this. After thorough mixing, the medium was dispensed by using a tilting measure to deliver $10 \mathrm{ml}$. to each plate. Twenty plates were prepared for each dilution, 10 plates with medium unsupplemented and 10 with antibiotics added. This seeding method was found in preliminary tests to be the most satisfactory for decreasing the spread of bacterial colonies developing on the plates. Plates were incubated at $25^{\circ}$ for 14 days; the most suitable dilutions for counting were selected and colonies of bacteria, actinomycetes and fungi were counted by using a plate counter with a magnifying lens. Counts were made after 7 and 14 days; whenever possible 14-day counts were selected but in some cases, especially on control plates, spreading fungi made counting after 14 days impossible.

Comparison of starch + casein medium plus antibiotics with some other media selective for actinomycetes. Plate counts of three soils obtained by using starch + casein with all four antibiotics and with the two antifungal ones only were compared with those obtained by using several other suggested media. These media were prepared according to the directions of the various workers and were as follows: $\mathbf{0 . 2} \%$ colloidal chitin medium (Lingappa \& Lockwood, 1962); water agar (Lingappa \& Lockwood, 1962); glycerol + arginine medium with antifungal antibiotics (Porter et al. 1960); glycerol + arginine + salts medium (El Nakeeb \& Lechevalier, 1963); egg 
albumin medium (Waksman, 1961). The preparation of dilution plates and counting procedures used were as described for the previous experiment.

\section{RESULTS}

\section{Selection of antibiotics}

Of the seven antibiotics tested against a range of actinomycetes, the antifungal ones (nystatin, actidione) did not inhibit any strains even at the highest concentration of $100 \mu \mathrm{g} . / \mathrm{ml}$. Similar results were obtained by Okami, Hashimoto \& Suzuki (1959) and by Porter et al. (1960). Of the antibacterial antibiotics, streptomycin, chloramphenicol and chlortetracycline inhibited 20-50\% of the strains even at the lowest concentration of $1.0 \mu \mathrm{g} . / \mathrm{ml}$. The least inhibition by antibacterial antibiotics was obtained by polymyxin B sulphate (no inhibition at $5.0 \mu \mathrm{g} . / \mathrm{ml}$.) and sodium penicillin (10\% strains inhibited at $1.0 \mu \mathrm{g} . / \mathrm{ml}$.). Therefore it was decided to use polymyxin B sulphate at $5.0 \mu \mathrm{g} . / \mathrm{ml}$. and sodium penicillin at $1.0 \mu \mathrm{g} . / \mathrm{ml}$. together with the two antifungal antibiotics for detailed testing.

Table 1. The effect of nystatin and actidione on the growth of the fungi tested

\begin{tabular}{|c|c|c|c|}
\hline ' & $\begin{array}{c}\text { Actidione } \\
(50 \mu \mathrm{g} \cdot / \mathrm{ml} .)\end{array}$ & $\begin{array}{c}\text { Nystatin } \\
(50 \mu \mathrm{g} . / \mathrm{ml} .)\end{array}$ & $\begin{array}{c}\text { Actidione } \\
(50 \mu \mathrm{g} \cdot / \mathrm{ml} .)+\mathrm{nystatin} \\
(50 \mu \mathrm{g} . / \mathrm{ml} .)\end{array}$ \\
\hline Percentage of fungi completely inhibited & 22 & 69 & 84 \\
\hline Percentage of fungi partially inhibited & 56 & 22 & 16 \\
\hline Percentage of fungi not inhibited & 22 & 9 & $\mathbf{0}$ \\
\hline
\end{tabular}

Table 2. The reaction of some soil fungi to actidione +nystatin (each $50 \mu \mathrm{g} . / \mathrm{ml}$.)

All the fungi tested were inhibited either completely or partially.

$\begin{array}{ll}\text { Fungi completely inhibited } & \text { Fungi partially inhibited } \\ \text { Pythium sp. } & \text { Mortierella alpina } \\ \text { Mortierella parvispora } & \text { Mortierella marburgensis } \\ \text { M. vinacea } & \text { Chadia spinosa } \\ \text { Mucor hiemalis } & \text { Paecilomyces carneus } \\ \text { M. ramannianus } & \\ \text { Zygorhynchus sp. } & \\ \text { Sordaria } \text { sp. } & \\ \text { Perisporium vulgare } & \\ \text { Basidiomycetes B 1, 2, 3 } & \\ \text { Phoma sp. } & \\ \text { Aspergillus sp. (a) } & \\ \text { Aspergillus sp. (b) } & \\ \text { Cladosporium herbarum } & \\ \text { Gliocladium roseum } & \\ \text { Oidiodendron fuscum } & \\ \text { Penicillium decumbens } & \\ \text { P. lanosum } & \\ \text { P. spinulosum } & \\ \text { Trichoderma viride } & \\ \text { Cylindrocarpon radicicola } & \\ \text { Fusarium culmorum } & \\ \text { Sterile dark forms } a, b & \end{array}$


Testing of selected antibiotics against actinomycetes, bacteria and fungi

Antifungal antibiotics. Nystatin and actidione were tested separately and together at $50 \mu \mathrm{g} . / \mathrm{ml}$. against a range of fungi isolated from soil; the results of these tests are given in Table 1. The highest percentage inhibition was obtained with nystatin and actidione together, none of the test fungi being completely resistant. When used separately, nystatin gave better results than actidione. The efficiency of the two together was largely due to the differences in their antifungal spectra rather than to synergistic action. Results obtained with $100 \mu \mathrm{g} . / \mathrm{ml}$. of each together were identical with those for the $50 \mu \mathrm{g} . / \mathrm{ml}$. concentrations.

\section{Table 3. The reaction of some soil bacteria to polymysin $B$ sulphate} $(5 \cdot 0 \mu \mathrm{g} . / \mathrm{ml})+$. sodium penicillin $(\mathbf{1} \cdot 0 \mu \mathrm{g} . / \mathrm{ml}$. $)$

Completely inhibited

Achromobacter anitratus (NCTC8102)

Bacillus laterosporus (NCTC7579)

B. licheniformis (NCTC7589)

B. pantothenticus (NCTC8162)

Bacillus sp.

Chromobacterium violaceum (NCrc9757)

Mycobacterium phlei (NCTC 8151)

Pseudomonas fluorescens

Sarcina lutea

Vibrio percolans
Partially inhibited

Arthrobacter sp.

B. megaterium

Pseudomonas chlororaphis (NCTC7537)
Not inhibited

Agrobacterium tumefaciens (NCPPB 397)

B. mycoides (NCTC926)

B. subtilis

Chromobacterium lividum (NCTC9796)

In Table 2 details of the reaction of individual species of fungi to nystatin + actidione are given. The fungi were chosen to cover a wide taxonomic range and to include species commonly occurring on soil dilution plates. Species such as Penicillium, Trichoderma viride, Cladosporium herbarum and Mucor hiemalis, which often spread widely on soil-dilution plates, were completely inhibited. It is interesting to note that the Pythium sp., the only representative of the Oomycetes tested, was not inhibited by nystatin alone. It was suggested by Kinskey (1962) that nystatin acts by altering the permeability of the chitinous cell membrane of sensitive fungi, so that lower Phycomycetes, which have more cellulose in their walls, are resistant.

The efficiency of nystatin + actidione was also compared with two other suggested antifungal agents, $\mathbf{0 . 4} \%(\mathrm{w} / \mathrm{v})$ sodium propionate in the medium (Crook, Carpenter $\&$ Klens, 1950) and the phenol treatment of suspensions (Lawrence, 1956). The results indicated that the antibiotics achieved a much greater selective inhibition of fungi, and that a mixture of nystatin + actidione (each $50 \mu \mathrm{g} . / \mathrm{ml}$.) added to the medium achieved efficient suppression of fungi on soil dilution plates.

Antibacterial antibiotics. Sodium penicillin $(1.0 \mu \mathrm{g} . / \mathrm{ml}$.) and polymyxin B sulphate $(5 \cdot 0 \mu \mathrm{g} . / \mathrm{ml}$.) were tested separately and together against a range of bacteria chosen to include types which commonly occur on soil dilution plates. Their reaction to a mixture of these antibiotics is given in Table 3. Many of the test strains were inhibited, but the results were not as convincing as those obtained with the antifungal antibiotics. Two bacterial species found frequently on soil dilution plates, namely Bacillus subtilis and $B$. mycoides, were resistant. 
Antifungal and antibacterial antibiotics together. All four antibiotics were next retested against the bacteria and fungi to ensure that their action was not impaired when they were together in the medium. The results were like those previously obtained.

The mixture of antibiotics was finally tested against a series of Streptomyces together with Micromonospora melanosporea, Waksmania rosea and Streptosporangium sp. The reaction of some named strains is given in Table 4; many commonly occurring soil types (e.g. Streptomyces griseus, S. lavendulae, S. flavovirens) tolerated the antibiotics as did also the representatives of the three other actinomycetes.

In Table 5 the overall effects of the antibiotic mixture on actinomycetes is compared with those on fungi and bacteria. These results, with high percentage inhibition of fungi, moderate inhibition of bacteria and low percentage inhibition of actinomycetes, indicated that this mixture of antibiotics might be used to improve the selectivity of the starch + casein medium for development of actinomycetes on soil dilution plates.

Table 4. The reaction of some actinomycetes to a mixture of the four antibiotics: actidione, nystatin, each $50 \mu \mathrm{g} . / \mathrm{ml}$., polymyxin $B$ sulphate $5 \cdot 0 \mu \mathrm{g} . / \mathrm{ml} .$, sodium penicillin $1.0 \mu \mathrm{g} . / \mathrm{ml}$.

Completely inhibited: Streptomyces glaucescens (ETH*24204), S. hygroscopicus (CBS)

Partially inhibited: S. purpureochromogenes (CBS)

Not inhibited: S. azureus (ETH 28555), S. albus (ATCC618), S. californicus (CBS), S. cinereoruber (ETH 7451), S. cinnamoneus (ETH 23996), S. diastaticus (CBS), S. coelicolor (CBS), S. flavovirens (CBS), S. griseolus (CBS), S. griseus (wc3475), S. halstedii (CBS), S. lavendulae (wc 3440/14), S. lipmanii (CBS), S. netropsis (ETH 24299), S. phaeochromogenes (CBs), S. venezuelae (CBS), S. violaceoruber (wC3030), S. viridochromogenes (CBS).

* ETH, Eidige Technische Hochshule, Zurich, Switzerland. CBS, Centraalbureau voor Schimmelcultures, Baarn, Netherlands. ATcc, The American Type Culture Collection, Washington, D.c., U.S.A. wc, The Waksman Collection, The State University, Rutgers, N.J., U.S.A.

Table 5. Summary of the effects of a mixture of 4 antibiotics (actidione, nystatin, each $50 \mu \mathrm{g} . / \mathrm{ml}$., polymyxin $B$ sulphate $5.0 \mu \mathrm{g} . / \mathrm{ml}$., sodium penicillin, $1.0 \mu \mathrm{g} . / \mathrm{ml}$.$) on$ actinomycetes, bacteria and fungi

$\begin{array}{lcccc} & \begin{array}{c}\text { Strains } \\ \text { completely } \\ \text { inhibited } \\ (\%)\end{array} & \begin{array}{c}\text { Strains } \\ \text { partially } \\ \text { inhibited } \\ (\%)\end{array} & \begin{array}{c}\text { Strains } \\ \text { not } \\ \text { inhibited }\end{array} & \begin{array}{c}\text { No. of } \\ \text { strains } \\ \text { tested }\end{array} \\ \text { Actinomycetes } & 6 & 1 \%) & \mathbf{1 3} & \mathbf{1 1 4} \\ \text { Bacteria } & 6 & 15 & \mathbf{2 0} & \mathbf{2 5} \\ \text { Fungi } & \mathbf{6 5} & \mathbf{1 6} & 0 & \mathbf{3 0}\end{array}$

Comparison of dilution plates prepared with and without antibiotics

Results obtained with the starch + casein medium, with and without the four antibiotics used to prepare dilution plates of four soils, are given in Table 6 . The pairs of figures marked with an asterisk were significantly different at the 0.01 probability level. It is evident that the presence of the antibiotics had little effect on the numbers of actinomycete colonies. In soils where numbers of fungal colonies on control plates were low (samples from Oxton and Freshfield, C horizon), numbers of actinomycetes colonies decreased slightly on the antibiotic medium, reflecting the inhibition of some propagules by the antibacterial antibiotics. For 
soils with higher numbers of fungal colonies on control plates (samples from Ness and Freshfield A horizon), the numbers of actinomycete colonies on the antibiotic plates were slightly higher. On these plates the inhibition of fungi, allowing the development and detection of more actinomycetes, more than counteracted the small degree of inhibition by the antibacterial antibiotics.

In contrast, the numbers of fungal and bacterial colonies were significantly decreased by the presence of the antibiotics. The decrease in bacterial colonies ranged from 55 to $81 \%$, while fungal colonies were completely eliminated with all the soil samples tested. It was noticed that the antibiotics decreased the rate of growth of some actinomycete colonies, their development lagging 4-5 days behind those on control plates. However, after incubation for 14 days, most colonies were well developed and often sporing heavily.

Table 6. Comparison of plate counts obtained on starch + casein medium unsupplemented and with 4 antibiotics

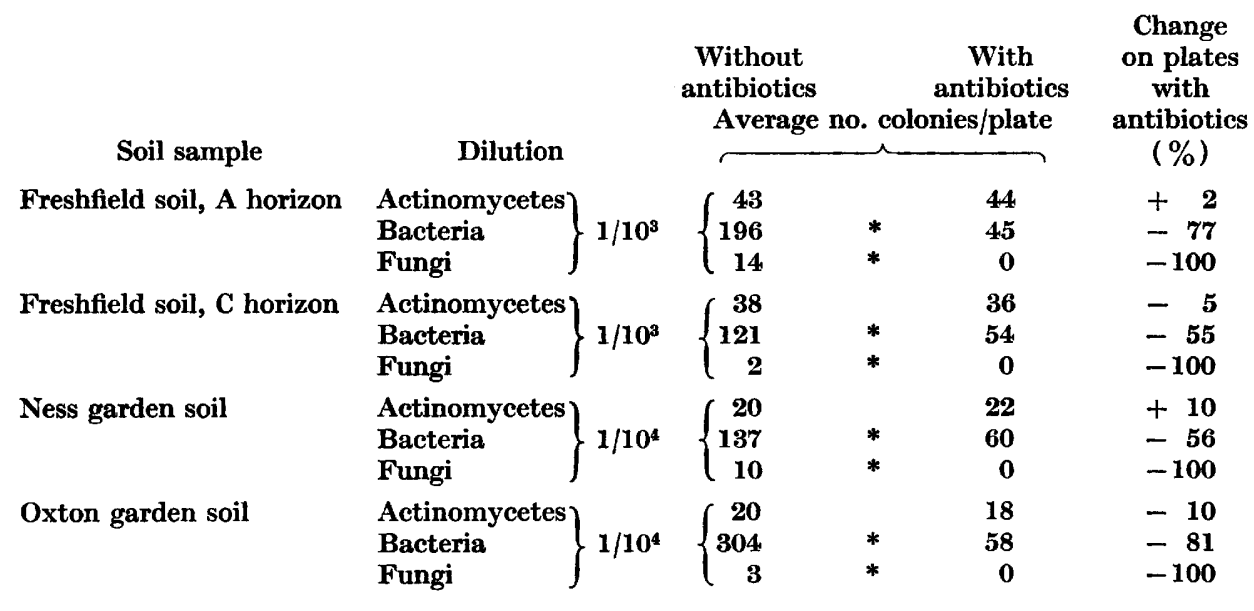

* Figures significantly different $(P=0 \cdot 01)$.

\section{Comparison of starch + casein medium + antibiotics with some other} media selective for actinomycetes

Plate counts of actinomycete colonies were obtained for three soils on starch + casein medium with all four antibiotics, the same medium with only the two antifungal antibiotics and five other media selective for actinomycetes. Details of these results are given in Table 7. Figures marked with an asterisk differed significantly $(P=0.01)$ from figures for the same soil obtained by using the starch + casein medium with all four antibiotics. Starch + casein medium containing the two mixtures of antibiotics and the chitin medium of Lingappa \& Lockwood (1962) gave significantly higher colony counts than the other media in all cases except for the figure for the Oxton soil plated on glycerol + arginine medium. The counts for the three soils obtained on the chitin medium and on starch + casein + antifungal antibiotics were very similar, and as might be expected the figures for the latter were higher than those for starch + casein medium with all four antibiotics. Of the two media with very similar composition (glycerol +arginine, Porter et al. 1960; 
arginine + glycerol + salts, El Nakeeb \& Lechevalier, 1963), the Porter et al. medium with the recommended addition of antifungal antibiotics gave slightly higher counts.

When the percentage composition of the colonies on the plates was considered, starch + casein medium +4 antibiotics clearly gave the highest percentage of actinomycetes, with the chitin medium second best. Starch + casein medium + antifungal antibiotics (nystatin, actidione) and the other media gave similar percentages of actinomycete colonies. Thus differences in the total numbers of actinomycete colonies on these media were paralleled by differences in numbers of bacterial colonies (the numbers of fungal colonies being too small to have a significant effect), indicating that the selectivity of these media for actinomycetes over bacteria was virtually the same.

Table 7. Comparison of results obtained by using several media selective for actinomycetes

\begin{tabular}{|c|c|c|c|c|c|c|c|c|}
\hline & & $\begin{array}{c}\text { Freshfiel } \\
\text { soil } \\
\text { horizon }\end{array}$ & & & & & & \\
\hline & $\begin{array}{l}\text { Oxton } \\
\text { soil }\end{array}$ & A & $\mathbf{C}$ & Average & & & & Average \\
\hline & & $\begin{array}{r}\text { dilution } \\
\left(1 / 10^{3}\right)\end{array}$ & & $\begin{array}{l}\text { of the } \\
3 \text { values }\end{array}$ & $\begin{array}{l}\text { Oxton } \\
\text { soil }\end{array}$ & & C & $\begin{array}{l}\text { of the } \\
3 \text { values }\end{array}$ \\
\hline & Aver & $\begin{array}{l}\text { ge no. actir } \\
\text { colonies/p }\end{array}$ & $\begin{array}{l}\text { nomy } \\
\text { plate }\end{array}$ & etes & & $\begin{array}{l}\text { ge } \% \\
\text { otal }\end{array}$ & $\begin{array}{l}\text { inom } \\
\text { ies } / p\end{array}$ & tes of \\
\hline $\begin{array}{l}\text { Starch }+ \text { casein } \\
\text { medium }+ \text { antifungal } \uparrow \\
\text { and antibacterial } \ddagger \\
\text { antibiotics }\end{array}$ & $t^{16}$ & 36 & 24 & $25 \cdot 3$ & 13 & $\mathbf{5 1}$ & 75 & $46 \cdot 3$ \\
\hline $\begin{array}{l}\text { Starch }+ \text { medium }+ \\
\text { antifungal antibiotics }\end{array}$ & $\mathbf{s}^{20}$ & 44 & 27 & $\mathbf{3 0} \cdot \mathbf{3}$ & 6 & 28 & 37 & $22 \cdot 0$ \\
\hline $\begin{array}{l}0.2 \% \text { chitin medium } \\
\text { (Lingappa \& } \\
\text { Lockwood, 1962) }\end{array}$ & 20 & 45 & 21 & $28 \cdot 7$ & 9 & 37 & 45 & $30 \cdot 3$ \\
\hline $\begin{array}{l}\text { Glycerol + arginine } \\
\text { medium (Porter } \\
\text { et al. 1960) }\end{array}$ & 13 & $27 *$ & $7 *$ & $15 \cdot 7$ & 5 & 21 & 33 & $19 \cdot 7$ \\
\hline $\begin{array}{l}\text { Arginine + glycerol + } \\
\text { salts (El Nakeeb \& } \\
\text { Lechevalier, 1963) }\end{array}$ & $11 *$ & 25* & $5^{*}$ & $13 \cdot 7$ & 8 & 18 & 38 & $21 \cdot 3$ \\
\hline $\begin{array}{l}\text { Egg albumin } \\
\text { (Waksman, 1961) }\end{array}$ & $11^{*}$ & $21 *$ & $4^{*}$ & $12 \cdot 0$ & 10 & 24 & 25 & $19 \cdot 7$ \\
\hline $\begin{array}{l}\text { Water agar } \\
\text { (Lingappa \& Lock- } \\
\text { wood, 1962) }\end{array}$ & 5* & $16 *$ & $6^{*}$ & $9 \cdot 0$ & 3 & 33 & 37 & $24 \cdot 3$ \\
\hline
\end{tabular}

* Figures significantly different from those obtained with starch + casein with all antibiotics $(P=0.01)$.

$\dagger$ Antifungal $=$ nystatin + actidione, each $50 \mu \mathrm{g} . / \mathrm{ml}$.

$\$$ Antibacterial $=$ polymixin $\mathrm{B}$ sulphate $5.0 \mu \mathrm{g} . / \mathrm{ml} .+$ sodium penicillin $1.0 \mu \mathrm{g} . / \mathrm{ml}$. 


\section{DISCUSSION}

When selecting media for the preparation of soil dilution plates it is important to distinguish between enumeration and isolation of the colonies which develop. For counting colonies, the most suitable media are those which allow development and detection of the maximum numbers of colonies of the organisms under study.

From the results obtained here, the most satisfactory media for counting actinomycete colonies were the starch + casein medium + the antifungal antibiotics, nystatin and actidione, and the chitin-containing medium. These gave similar numbers of actinomycete colonies; starch + casein medium + antibiotics allowed development of more bacteria (an average of 165 colonies/plate compared with 101 for chitin) and hence gave a lower percentage of actinomycete colonies. However, use of the chitin medium had certain disadvantages : the opalescence of the medium made detection and classification of small colonies difficult, particularly when these did not clear the medium. Some actinomycete colonies developed well and cleared the surrounding medium, but others were almost pin-point colonies and were difficult to distinguish from bacteria without microscopic examination. Also the development of pigments, so characteristic of many actinomycetes, did not occur on this chitin-containing medium. It must be noted that use of the chitin medium without antibiotics, as recommended by Lingappa \& Lockwood, allowed development of fungi (an average of 5 colonies/plate) which although growing thinly had a large radial spread. Therefore the starch + casein medium + nystatin + actidione, being a clear medium and allowing good development of aerial mycelium and of pigmentation, is considered to be the most suitable for the enumeration of actinomycete colonies.

For isolation purposes, a medium should give a reasonably high total numbers of the organisms under study and these should comprise as high as possible a percentage of the population on the plates to minimize overgrowth by other groups. The media best fulfilling these requirements for actinomycetes were the starch + casein medium + the 4 antibiotics and the chitin-containing medium. Of these, starch + casein + antibiotics gave lower numbers of colonies but a higher percentage of actinomycete colonies due to its greater selectivity against bacteria (an average of 49 colonies/plate compared with 101 for the chitin medium). Most of the disadvantages of the chitin medium already outlined also apply when it is used for the isolation of actinomycetes. Lack of distinguishing pigmentation prevents any preliminary grouping of the colonies on the plates, so all have to be transferred to another medium. Comparison of the number of different types of actinomycetes isolated from the two Freshfield soils by random selection and transfer of colonies showed no significant difference between the numbers obtained from the starch + casein +4 antibiotics, starch + casein + nystatin + actidione only, and the chitin medium. Therefore the most suitable medium for the isolation of actinomycetes was the starch + casein medium +4 antibiotics. However, the antibacterial antibiotics in this medium inhibited the development of some actinomycetes, so that the results obtained for a soil depended on the numbers and proportions of susceptible strains present. It is therefore advisable to conduct a preliminary experiment comparing results with and without the antibacterial antibiotics, before using this method in an ecological investigation. 
The potentialities of using antibiotics to prepare soil dilution plates have been discussed. However, their use also permits the application to ecological studies of soil actinomycetes of several other techniques which have been shown to have considerable value in studies of the ecology of soil fungi. Most of these are not normally applicable to actinomycetes because of their low competitive ability on plates in the presence of bacteria and fungi. Preliminary work has been carried out on the isolation of actinomycetes from various micro-habitats in soil by using starch + casein medium +the 4 antibiotics. These micro-habitats included mineral and organic particles washed by the technique described by Parkinson \& Williams (1961) and Williams, Parkinson \& Burges (1965) and macerated washed roots of Pinus nigra. Such approaches have theoretical advantages over the use of dilution plates; there is a greater chance of isolating organisms from active mycelium, and separate soil micro-habitats can be studied. From the practical viewpoint, the plates obtained are much more easily and accurately analysed. It is felt that such techniques could be applied profitably in future studies on the ecology of actinomycetes in soil.

We would like to express our thanks to Dr R. Hütter, Eidige Technische Hochschule, Zurich, for providing some of the Streptomyces cultures. One of us (S. T.W.) conducted this investigation during tenure of a Department of Scientific and Industrial Research Fellowship.

\section{REFERENCES}

Agate, A. D. \& Bhat, J. V. (1963). A method for the preferential isolation of actinomycetes. Antonie van Leeurvenhoek, 29, 297.

Corbaz, R., Gregory, P. H. \& Lacey, M. E. (1963). Thermophilic and mesophilic actinomycetes in mouldy hay. J. gen. Microbiol. 32, 449 .

Corke, C. T. \& Chase, F. E. (1956). The selective enumeration of actinomycetes in the presence of large numbers of fungi. Can. J. Microbiol. $2,12$.

Conke, C. T. \& Chase, F. E. (1964). Comparative studies of actinomycete populations in acid podzolic and neutral mull forest soils. Soil Sci. Soc. Amer. Proc. 28, 68.

Crook, P., Carpenter, C. C. \& Klens, P. F. (1950). The use of sodium propionate in isolating actinomycetes from soils. Science, 112, 656 .

Dulaney, E. L., Larsen, A. H. \& Stapley, E. O. (1955). A note on the isolation of microorganisms from natural sources. Mycologia, 47, 420.

El-NAKeEb, M. A. \& Lechevalier, H. A. (1963). Selective isolation of aerobic actinomycetes. Appl. Microbiol. 11, 75.

Jornson, L. F. (1957). Effect of antibiotics on the numbers of bacteria and fungi isolated from soil by the dilution plate method. Phytopathology, 47, 630 .

KINSKY, S. C. (1962). Nystatin binding by protoplasts and a particulate fraction of Neurospora crassa, and a basis for the selective toxicity of polyene antifungal antibiotics. Proc. nat. Acad. Sci., Wash. 48, 1049.

Küster, E. \& Williams, S. T. (1964). Selection of media for isolation of streptomycetes. Nature, Lond. 202, 928.

LAWRENCE, C. H. (1956). A method of isolating actinomycetes from scabby potato tissue and soil with minimal contamination. Can. J. Bot. 34, 44.

LingaPPA, Y. \& Lockwood, J. L. (1961). A chitin medium for isolation, growth and maintenance of actinomycetes. Nature, Lond. 189, 158.

LingaPPA, Y. \& Lockwood, J. L. (1962). Chitin media for selective isolation and culture of actinomycetes. Phytopathology, 52, 317. 
Martin, J. P. (1950). The use of acid, rose bengal and streptomycin in the plate method for estimating soil fungi. Soil Sci. 69, 215.

Okami, Y., Hashimoto, T. \& Suzuki, M. (1959). Sensitivity of actinomycetes to antibiotics as a guide to identification. Symp. Taxonomy of Actinomycetes, Tokyo, Japan (1959), 223.

Parkinson, D. \& Williams, S. T. (1961). A method for isolating fungi from soil microhabitats. Plant and Soil, 13, 347.

Porter, J. N., Wilhelm, J. J. \& Tresner, H. D. (1960). Method for the preferential isolation of actinomycetes from soil. Appl. Microbiol. 8, 174.

ŘEнÁČEK, Z. (1959). Isolation of actinomycetes and determination of the number of their spores in soil. Microbiology, 28, 220.

TSAO, P. H., Leben, C. \& KeITT, G. W. (1960). An enrichment method for isolating actinomycetes that produce diffusible antifungal antibiotics. Phytopathology, 50, 88.

Waksman, S. A. (1961). The Actinomycetes. 2. Classification, Identification and Description of Genera and Species. Baltimore: The Williams and Wilkins Co.

Williams, S. T., Parkinson, D. \& Burges, N. A. (1965). An examination of the soil washing technique by its application to several soils. Plant \& Soil. (In the Press.) 